\title{
PRELIMINARY STUDY FOR THE ADAPTATION OF THE "HEAVEN'S CAVE" FOR TOURIST PURPOSES (PHONG NHA-KE BANG NATIONAL PARK, VIETNAM)
}

\author{
PREDHODNA ŠTUDIJA ZA TURISTIČNO UREDITEV NEBEŠKE \\ JAME (NARODNI PARK PHONG NHA-KE BANG, VIETNAM)
}

\author{
Bogdan DEBEVEC ${ }^{1} \dagger$, Martin KNEZ ${ }^{2}$, Andrej KRANJC ${ }^{2}$, Marko PAHOR ${ }^{3}$, Mitja PRELOVŠEK ${ }^{2}$, Aleš SEMEJA \\ \& Tadej SLABE ${ }^{2}$
}

\begin{abstract}
UDC 911.2:551.435.84(597)

551.435.84:338.48(597)

Bogdan Debevec, Martin Knez, Andrej Kranjc, Marko Pahor, Mitja Prelovšek, Aleš Semej \&, Tadej Slabe: Preliminary study for the adaptation of the "Heaven's Cave "for tourist purposes (Phong Nha-Ke Bang national park, Vietnam)

Heaven's Cave is located in the centre of the Phong Nha-Ke Bang national park, about $500 \mathrm{~km}$ southern from the Vietnamese capital and $40 \mathrm{~km}$ from the city of Dong Hoi. Phong NhaKe Bang national park is protected also as a UNESCO world heritage site. Due to weak economic situation in this region as a result of lack of natural resources, karst tourism represents an important opportunity for raising the quality of live in the province. A proposal to adapt non-touristic Heaven's Cave for tourism was presented to Karst Research Institute ZRC SAZU in 2006. Because the caves are sensitive ecosystems and all activities in them should be carefully implemented, our task was to make basic survey and map the cave, to perform a speleological and touristic research, to propose possible interventions for adapting the cave for tourism and to prepare a strategy for tourism development in this area. The latter should also show us if some interest is present among tourists for new show cave in this region. From this point of view this study does not represent systematic long-term approach for adapting a cave for tourism but rather a short study of a cave with potential to be show cave in remote area of Central Vietnam. Approach used in this study should be used in similar environments as a first step to estimate if weakly known cave is environmentally and economically suitable for development for touristic purposes. Keywords: Heaven's Cave, Thien Duong Cave, Phong Nha-Ke Bang, Vietnam, show cave.
\end{abstract}

Izvleček

UDK 911.2:551.435.84(597)

$551.435 .84: 338.48(597)$

Bogdan Debevec, Martin Knez, Andrej Kranjc, Marko Pahor, Mitja Prelovšek, Aleš Semeja \& Tadej Slabe: Predhodna študija za turistično ureditev Nebeške jame (narodni park Phong Nha-Ke Bang, Vietnam)

Nebeška jama leži v središču narodnega parka Phong Nha-Ke Bang približno $500 \mathrm{~km}$ južno od vietnamske prestolnice in $40 \mathrm{~km}$ od najbližjega mesta Dong Hoi. Pomen narodnega parka Phong Nha-Ke Bang v svetovnem merilu izdaja dejstvo, da je uvrščen na UNESCO seznam svetovne dediščine. Zaradi slabe ekonomske situacije v regiji, ki je rezultat skromnih naravnih virov, predstavlja kraški turizem pomembno priložnost za izboljšanje kvalitete življenja. V tej smeri je bil Inštitutu za raziskovanje krasa ZRC SAZU v letu 2006 predstavljen predlog za turistično ureditev Nebeške jame. Ker predstavljajo jame občutljiv ekosistem, vse aktivnosti v njih pa morajo biti skrbno pretehtane, je $\mathrm{v}$ okviru naših ključnih nalog izvedli osnovne meritve jame, izdelali načrt jame, jamo strokovno in turistično ovrednotili, predlagali možne ukrepe za vzpostavitev turistične jame in izdelali strategijo turističnega razvoja območja. Raziskava v okviru namena strategije bi tudi pokazala, kakšen je interes s strani turistov po odpiranju nove jame za turistične namene. Zaradi kratkosti in enostavnosti raziskav študija ne temelji na sistematičnem dolgotrajnem pristopu za namen turistične ureditve, ampak bolj temeljno študijo $\mathrm{z}$ oceno turističnega potenciala jame v odmaknjenem območju Vietnama. Pristop, ki smo ga uporabili pri tej študiji, je lahko $\mathrm{v}$ podobni obliki uporabljen tudi $\mathrm{v}$ drugih podobnih okoljih kot prvi korak pri odločitvi ali so pri ureditvi jame za turizem izpolnjeni vsi okoljski in ekonomski pogoji.

Ključne besede: Nebeška jama, jama Thien Duong, PhongNha-Ke Bang, Vietnam, turistična jama.

\footnotetext{
1 Turizem KRAS d.d., Jamska cesta 30, SI-6230 Postojna, Slovenia

${ }^{2}$ Karst Research Institute ZRC SAZU, Titov trg 2, SI-6230 Postojna, Slovenia, e-mails: knez@zrc-sazu.si, andrej.kranjc@sazu.si, mitja.prelovsek@zrc-sazu.si, slabe@zrc-sazu.si

${ }^{3}$ Ekonomska fakulteta Univerze v Ljubljani, Kardeljeva ploščad 17, Ljubljana, e-mail: marko.pahor@ef.uni-lj.si

${ }^{4}$ Sava TMC d.o.o., Škofjeloška cesta 6, SI-4000 Kranj, Slovenia, e-mail: ales.semeja@sava.si
}

Received/Prejeto: 15.11.2011 


\section{INTRODUCTION}

Quang Binh Province, situated about $500 \mathrm{~km}$ south from the capital Hanoi, is one of the poorest provinces of $\mathrm{Vi}$ etnam (per capita GDP is half the Vietnamese average). With the aim of improving the economic situation in the area, the possibility has been raised of marketing sights in the Phong Nha-Ke Bang National Park, a UNESCO World Heritage Site as tourist attractions. Among these sights, as yet unexploited for tourism purposes, is Heaven's Cave (in Vietnamese Thien Duong). In the year 2006, Karst Research Institute ZRC SAZU was invited by Vietnamese company CivideC to cooperate on development of the Thien Duong (Heaven's Cave) for tourism. Research was supported by Vietnamese local government and Slovene scientific programme Promotion of Science funded by Slovene Ministry of Higher Education, Science and Technology.

The Phong Nha-Ke Bang National Park covers an area of $857.54 \mathrm{~km}^{2}$ and is a UNESCO World Heritage Site, reflecting its global importance (World Heritage List Nomination Form 2000). The park came under UNESCO protection in 2003 because of its extraordinary stratigraphical diversity (from the Precambrian to the present day - over 400 million years), the long development of its topography (from the Oligocene to the present day - over 36 million years) and the resulting extremely intensively developed tropical karst formations (Fig. 1). Over 300 karst caves have been recorded in the park (Limbert 2010b), among which the most extensive is Hang Vom Cave system with $15,310 \mathrm{~m}$ long cave passages (Limbert 2010a, 2010c). In the last 2 years, the park is known also due to the biggest river cave in the world, Hang Son Doong (Hamilton-Smith 2009). The park's geological and geomorphological diversity is closely followed by its considerable biodiversity in terms of both fauna and flora, and its extraordinarily well conserved tropical karst forests.

The surface of the Phong Nha-Ke Bang Park is hilly. The highest-lying area, with peaks of over 1,100 metres, runs along the Vietnam-Laos border, after which the land is generally inclined towards the north-east. The central section is crossed by the Chay River, the lowest point in the park ( 80 metres above sea level). Conical hills with depressions between them account for the majority of geomorphic forms. The depressions can be between 100 and 300 metres deep. The slopes are very steep and as a rule exceed the slope angle of scree $\left(30-35^{\circ}\right)$. Individual areas of cone karst are bisected by individual river valleys into which sinking (allogenic) waters and percolation (autogenic) waters flow.

The central limestone area is bordered by impermeable strata which collect water on the surface and in the southern part of the park discharge it towards the Chay River lying further north. This inflow of allogenous water, combined with the long development, is the main factor of the development of the underground caves explored to date. Excellent examples of caves of this type are the Phong Nha (show cave) and Hang Vom Cave systems. With the entrenchment of the Chay River, the underground flows shift lower and lower and leave fossil caves at the higher levels. Examples of such caves are Tien Son Cave, rich in calcite deposits and open to tourists as a show cave, and Heaven's Cave (name of the cave was proposed by Vietnamese collaborators). The caves follow the bedding planes into the thickly stratified Devonian-Carboniferous-Permian limestone and numerous faults tied to the predominantly $\mathrm{N}-\mathrm{S}$ faults in the Alpine orogen (World Heritage List Nomination Form 2000). Long-term karstification is also facilitated by limestone strata over 1,000 metres thick.

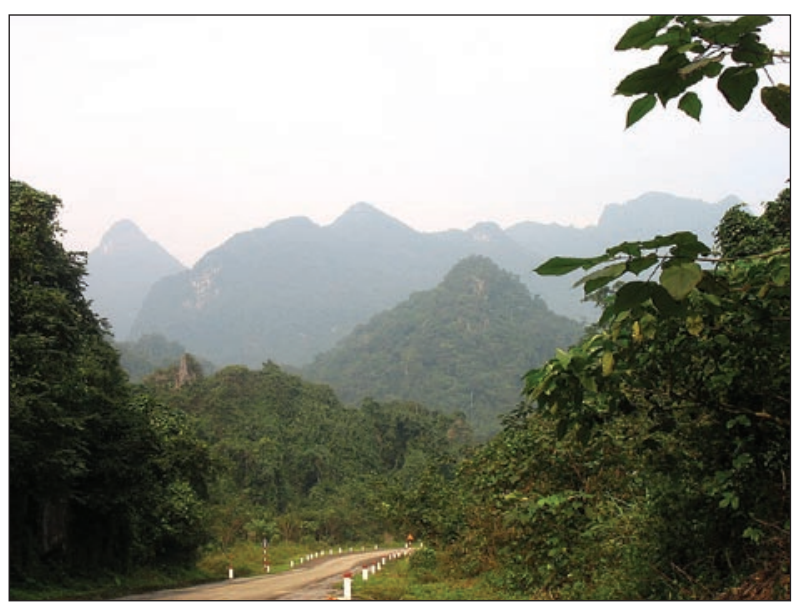

Fig. 1: Tropical karst in the middle of the Phong Nha-Ke Bang national park (Photo: M. Knez).

The wonderful sandy beaches western of South China Sea and the Phong Nha-Ke Bang National Park represent considerable development potential. Since Heaven's Cave lies at the heart of the national park and represents a potential for tourist development, the bulk of our research was directed towards surveying, an expert study of the cave and the possibility of turning it into a show cave. The study followed the standard procedure of Environmental Impact Assesment proposed by Cigna (2000). The first task was to measure the cave in order to establish its ground plan, longitudinal profile and significant cross-sections. At the same time a speleological evaluation of the cave is being carried out, in other words a description of the current state as regards geology, geomorphology, hydrology, meteorology, spe- 
leobiology and archaeology and palaeontology. The description of the current state includes a photographic inventory of significant elements of the cave. On the basis of these characteristics of the cave, the risks to and vulnerability of the cave is defined, and fundamental nature protection guidelines highlighted. The second part of the research presents a range of identified tourist attractions with a proposal of access to them (type and route of path for tourists) and a proposal of illumination. Use of the cave as a show cave must correspond to sustainable nature protection guidelines, since only in this way can we maintain the cave in its natural equilibrium. Access to the cave is very important. This is based on the proposed use of the cave as a show cave (number and type of visitors), the carrying capacity of the external environment and UNESCO guidelines.

\section{CAVE SURVEYING AND MAPPING}

Survey of $850 \mathrm{~m}$ of entrance parts of the Heaven's Cave and characteristics of its continuation showed that a Heaven's Cave is a part of 15,310 m (Limbert 2010b) long cave system Hang Vom. The latter was researched and surveyed in 1992 by British Cave Research Association. At that time, cavers entered the cave system Hang Vom through the main entrance where the water appears from the underground system. They exit Hang Vom through the upper entrance, which acts as a sink, and through the side entrance under the steep cliff. Because of dense jungle below the cliff they returned through the known, lower entrance (World Heritage List Nomination Form 2000, 18). Therefore, the side exit of Hang Vom and Heaven's Cave is supposed to be a part of the same cave system.

\section{GENERAL CAVE DESCRIPTION}

Entrance to Heaven's Cave is located at about $226 \mathrm{~m}$ a.s.1. under the vertical cliff. Entrance part is quite narrow since it leads through collapse blocks, which accumulated over the long geomorphic development at the foot of a cliff. The easiest access leads through $3 \times 4 \mathrm{~m}$ void between collapse blocks. The continuation is developed as $65 \mathrm{~m}$ long slope with inclination $45^{\circ}$. The upper part is formed by solid rock whereas the lower part is developed as a steep scree. In the middle of a scree, two over $5 \mathrm{~m}$ high and $3 \mathrm{~m}$ wide stalagmites are located. Foot of a scree is cov-

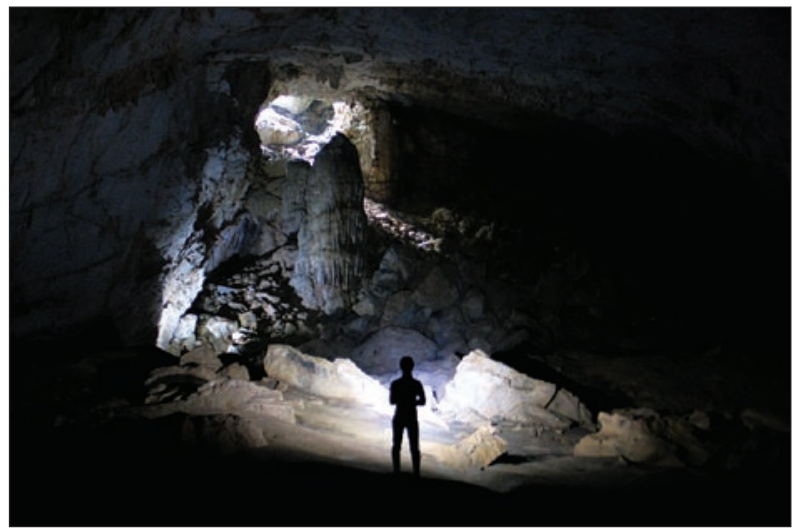

Fig. 2: Entrance chamber with impressive stalagmite close to the entrance (Photo: M. Prelovšek). ered by silty and loamy sediment and by bat guano. This part of the cave is actually a huge underground chamber $120 \mathrm{~m}$ long, $60 \mathrm{~m}$ wide and up to $30 \mathrm{~m}$ high (Fig. 2). At the southern side, dry water channel is located.

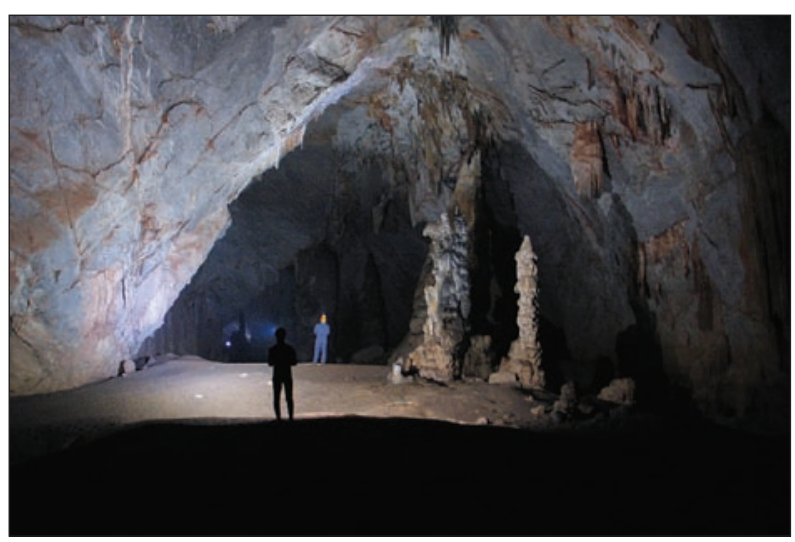

Fig. 3: Main passage in the Heaven's Cave (Photo: M. Prelovšek).

Downstream continuation is blocked with collapse material and loamy sediments, whereas the upper continuation of the cave leads toward the west. Bottom of the cave is covered with several meters wide rimstone dams, which are partially covered with mud but active 
since the calcite crystals are not corroded by mud deposits. The deepest exceed $1 \mathrm{~m}$ and is usually partly filled with water. The other seems to be mostly dry but the water can fill them after strong precipitation (Fig. 5). Another area of rimstone dams is located south-western of the first ones. There, cave passage is developed as about $30 \mathrm{~m}$ wide and more than $20 \mathrm{~m}$ high nearly horizontal passage. All along this main passage (Fig. 3), dry water channel is incised into the sediment terrace at both sides of a passage. Where the channel meanders, left or right terrace are often absent. Since the terrace is the driest part of the cave bottom, several stalagmites and columns appear there. Rather than individually, they are formed as a group under the well-cracked and karstified carbonate rock. The most impressive was named after palm tree - Cot Nhu Da. Continuation of a passage is similar to the already described parts of the cave.

\section{SPELEOLOGICAL EVALUATION OF HEAVEN'S CAVE}

Cave was investigated in details from geological, geomorphological and hydrological point of view. Other scientific disciplines (for example speleobiology, meteorology, archeology) should be deepend in the future.

\section{CAVE GEOLOGY}

The area in which the cave lies consists for the most part of carbonate rock. The structure of the rock is quite complex since there are frequent intercalations of various terrigenous sediments. It is often not possible to distinguish clearly the individual formations. The most extensive stratigraphic unit in the park is the so-called Bac Son formation of Carboniferous-Permian age in which we find predominantly massive and thick-bedded black to grey limestone, dolomitized limestone, lightly silificated limestone and in places numerous foraminifera and tetracoralla. The cave being researched also formed in this formation.

During detailed research in the cave, we established that the rock is highly recrystallized, partly dolomitized and highly bituminous black limestone.

The limestone has a general dip towards the south, the strata are between $10 \mathrm{~cm}$ and several dozen $\mathrm{cm}$ thick and have an inclination of around $30^{\circ}$. The limestone is massive in places, very probably partly as a result of extensive metamorphic processes.

In some sections synsedimentary breccia can be observed, in which there are clasts ranging in size from a few $\mathrm{cm}^{3}$ to a diameter of over $10 \mathrm{~cm}$. In some sections the rock is also laminated. The surface of the rock is for the most part weathered to a depth of a few $\mathrm{mm}$. White calcite powder can be observed on the surface.

The carbonate rock is highly fractured and contains numerous calcite veins and large fissures which for the most part are filled with calcite. The large fissures run in various directions and in many places it is not possible to determine their direction with accuracy because of the polished rock. In some sections characteristic boxwork has formed as a result of corrosion processes.

There are almost no fossil remains in the rock. Some horizons contain crinoids and other unrecognisable fossils due to metamorphosis. Just in one bed we discovered numerous remains of slightly recrystallized corals of a diameter of up to $1.5 \mathrm{~cm}$.

Speleothems cover approximately a third of the cave walls.

\section{CAVE GEOMORPHOLOGY}

The basis of the cave is a horizontal water passage between 20 and 40 metres wide and between 10 and 45 metres high and with no side passages of similar size (Fig. 3). The actual height of the basic corrosion passage is even greater, since the lower part of the passage is filled with loamy sediments and partially covered by speleothems. Given the horizontal orientation of the passage, we envisage that it formed at the height of a water level that remained stable for a long time at a height of around 180 metres above sea level, i.e. around 110 metres above the current bottom of the valley of the Chay River. As a result of the later reshaping of the cave by periodic, slowflowing flood waters, traces of the original watercourse can hardly be observed on the walls. Similarly, there are only a few traces in the cave of the gravelly and sandy sediments which could have been carried into the cave in the period when the prevailing inflow of water was allogenic.

The displacement of the water to lower active passages means that Thien Duong Cave is considerably isolated from active water flows. Allogenic water now only enters the cave during strong and prolonged rainfall. On passing from smaller channels with fast-flowing water into larger channels where the flow is slower, flowing water deposits allochthonous sediment (silt and clay, small amount of gravel and sand). The dimension of the main cave passage does not correspond to the occasional and 
relatively small quantities of water that flow through it. The cave's bottom out of the water channel is used for deposition of silty sediments at the time of severe floods that rise up to $4 \mathrm{~m}$ above the bottom of the channel. The water enters the passage through the ceiling in the form of currents and through small channels formed in the floor of the underground river bed. As a result of changes in the water level, washing away and subsidence of deposited sediment also occurs. Collapses are more common at the cave entrance since here the possibility of sediment being carried away is greatest. The profiles of the sediments in the sludge show that flooding was not uniform through the cave. Beneath the top layer of loam we find, in places, a calcite stratum over 1 metre thick and, below it, a greater thickness of flood loam. We can therefore trace the period when for unknown reasons the cave was out of reach of flooding for a longer period.

The absence of an active water flow also allowed calcite to be deposited from percolating water in the form of short stalactites, considerably larger stalagmites and pillars, and rimstone dams. These last are the greatest tourist attraction of the cave, since they are of aboveaverage dimensions and are perfectly conserved. Owing to their fragility they are also most at risk in the case of unsuitable waking through the cave.

\section{CAVE ROCK RELIEF}

The rock forms that constitute the relief are along-sediment rock forms, rock forms hollowed out by the flow of water, and composite rock forms. The formation of the
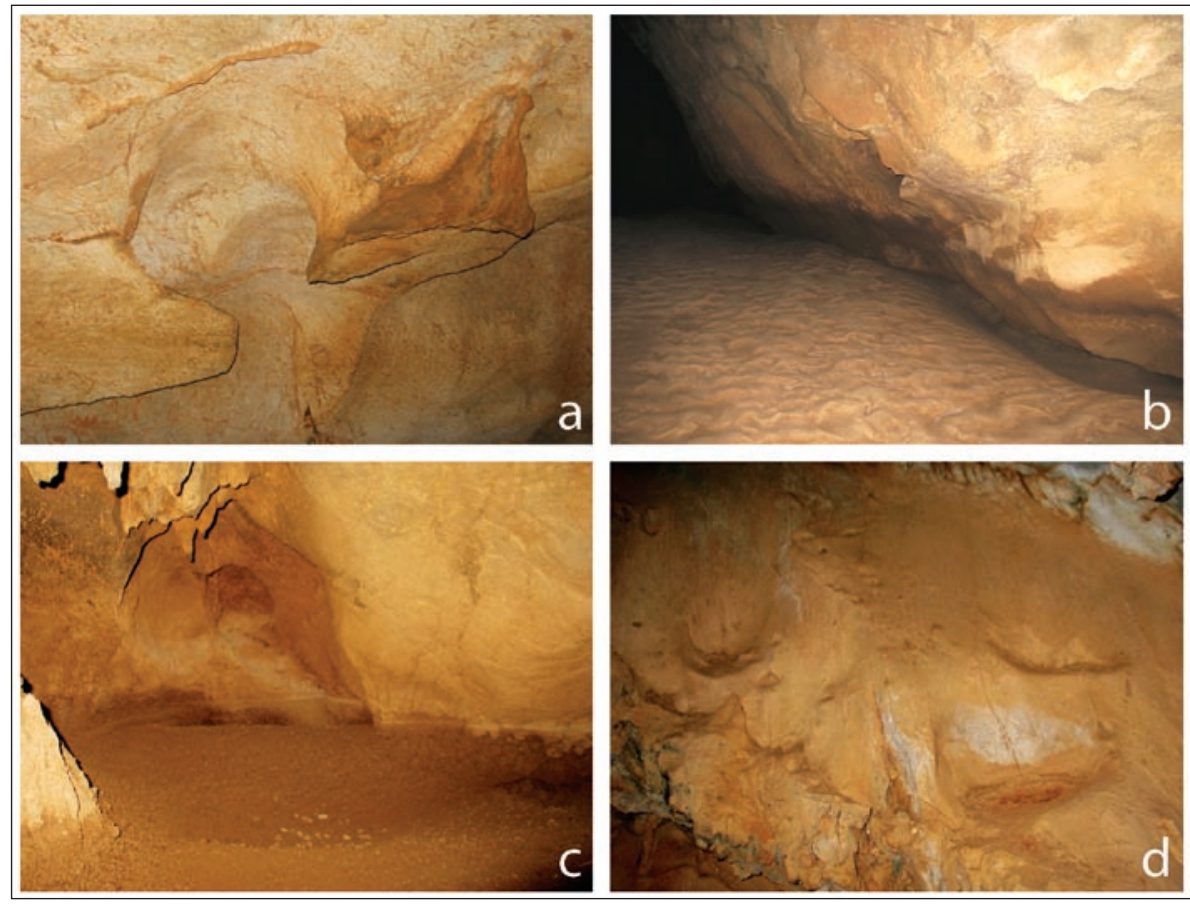

majority of rock forms is influenced by the fine-grained sediment deposited by water on the passage bottom and the peripheral rock (Fig. 4), and by the water that flows through the passage and hollows out the rock. The rock relief is important evidence of the way in which the cave has formed and developed and, indirectly, of the process of karstification of this tropical karst.

Along-sediment rock forms are the most distinctive and predominate on the periphery of the cave. Alongsediment notches (Fig. 4b) indicate that the sediment covering the wall remained at the same level for a longer period. Water that flows above the sediment hollows the rock, and its indentation is also faster when damp sediment is present. They are therefore longitudinal, more or less horizontal rock forms which we can follow through the entire length of the passage. They do however vary in shape and size. The first type are the uniformly overhanging lower sections of the walls. These can be several metres high. They form as a result of the even and prolonged filling of the tunnel with fine-grained sediment. At their periphery are semicircular notches with a diameter of up to a metre which are the trace of relatively shorter periods of the sediment level. Those which are indented more deeply into the wall and with a clearer overhang have ceiling pockets or above-sediment channels.

The second type of wall notches are the below-sediment notches. These form on the upper surfaces of inclined rock beds. The flow of water has cut more deeply into the wall of the passage along the bedding planes and high flood waters deposit fine-grained sediment in the lower parts of the notches. This sediment protects these parts from the flow of water, which above all widens and raises the notches, while at the same time corrosion below the damp sediment slowly levels the lower surfaces of the notches, above which the semicircular upper section rises in an arch. Below-sediment steps (Fig. 4d) are formed in a similar way. They divide more gently

Fig. 4: Cave rock forms commonly found in the Heaven's Cave: (a) above-sediment channel, (b) along-sediment notch, (c) estavelle, (d) below-sediment steps (Photos: T. Slabe). 
sloping walls. They are hemispherical notches with more or less horizontal lower surfaces which are covered by fine-grained sediment. In the sections of wall where this is possible, i.e. where there is weakness in the rock (in this case mainly interruptions in the sedimentation and fissures), flood waters deposit a small quantity of sediment. Below-sediment pits start to form below it, in time growing into steps with a diameter of up to a metre and more.

Above-sediment channels (Fig. 4a; Slabe 1995) form as a result of the flow of water above the fine-grained sediment which it deposited in the passage. Their formation and development is well known, but new findings offer various connections of above-sediment channels to composite rock forms. They are often found on the ceiling of along-sediment wall notches. They run along their ceiling or from a wall notch, and thus split its upper edge. The largest channels are stepped. Smaller notches cut into the ceiling of a larger one, and their diameters can be greater than a metre. This indicates the changing level of fine-grained sediment in the passage. In the largest channels, which became smaller due to gradual sedimentation, there are pockets on the ceiling. Ceiling channels also crisscross the ceilings of estavelles which form by an overhanging wall in contact with sediment, and even estavelles themselves can be defined as large ceiling channels. Water also flows into the passage in an upwards direction from below and estavelles form along the walls (Fig. 4c) and in the middle of the passage. This is a trace of considerable fluctuation of the water level in the aquifer.

Rock forms hollowed by the flow of water, which are the most distinctive rock forms of this type found throughout the passage, are ceiling pockets. The eddying of the water flow is the predominant factor in their formation, while their position is often connected to the changing levels of fine-grained sediment. They are often a constituent part of along-sediment rock forms. They vary in shape and size. They are simple (Slabe 1995), composite and multi-level, independent or connected in domes; by fissures they have an elliptical cross-section and often appear in a series, one next to the other. They divide entire ceilings of lower passages and the lower parts of larger passages or are a part of composite rock forms, along-sediment wall notches and niches and large above-sediment channels. The hydraulic characteristics dictated by the shape of the passage and its varying size are also evident in the shape and disposition of the ceiling pockets on the inflow and outflow sides of the lower parts of the ceiling, where they are connected in an upright series - in other words they are one above the other and relatively shallow. The shape of wall pockets is also affected by the sediment deposited by the water in their lower sections, which over time becomes flat. As a rule a wall pocket also forms above the mouth of estavelles.

Wall niches form as the mouths of estavelles and as a result of the eddying of the water above the sediment that covers the floor of the passage. Some form above inflows of water that eddies when it reaches the passage. Others form as a result of the eddying of the water against the wall immediately above the sediment covering the floor of the passage. Rock forms which are the result of the slower flow of water through the passage thus predominate.

Dominant factors alternate in the composite rock forms formation, or else younger factors cover the traces of older ones. Almost the majority of rock forms in the passage are composite. The most characteristic forms are the wall notches, niches and ceiling channels and belowsediment wall pockets already described.

Exposed sediment wall notches which, in view of the fall in the level of sediment in the passage, indicate the former filling of the passage, often have pockets on the ceiling which are traces of the eddying of the water flow. Above-sediment ceiling channels, on the other hand, are evidence of a higher level of sediment, when this reached all the way up to the top of the notch and only a small quantity of water flowed into it and cut its way into the rock. The niches which form as the mouths of estavelles along overhanging walls surrounded by fine-grained sediment have a similar formal composition. The greater diameter of the estavelle dictates a more abundant flow of water and more eddying, and the consequent formation of ceiling pockets. Once these are to a large extent filled with sediment, above-sediment ceiling channels form. Ceiling pockets are sometimes to be found at the top of larger above-sediment ceiling channels. Abovesediment wall pockets are asymmetric hemispheres in shape, while the lower part of their periphery is more or less flat. The fine-grained sediment which is deposited on it influences their development.

The rock periphery is transformed by the corrosion of water, which condenses on the cave walls and ceiling. This affects above all the rock surface, which divides into "boxwork" or else notches form along small fissures. Chert juts more noticeably from the wall (up to $10 \mathrm{~cm}$ ) either individual lenses or whole strata.

Today's high water levels reach to an average of a metre and a half above the sediment, transform the lower part of the periphery of the passage and entirely fill passages of smaller dimensions. The rock relief of the upper part of the periphery of larger passages is a trace of the former formation of the cave. The passage has a characteristic cross-section. Its more extensive sections have, above the floor, overhanging walls of below-sediment formation, which indicates the longest duration of 
the filling of the lower parts of the passage with sediment and the resulting corrosion.

The frequent flooding and filling of the cave with fine-grained sediment, which also conditions the development of the unique but characteristic rock relief and the cross-section of the passages, may be tied to periods of copious monsoon rainfall, which in their own way shape and hollow out this tropical cone karst.

\section{CAVE HYDROLOGY}

Although the cave was dry in the time of our first and second visit and without any important flow of water, well-developed but usually dry water channel points out on periodical water flow within a cave. Cross-section of a water channel ( 3-5 $\mathrm{m}$ wide and $\sim 1-2 \mathrm{~m}$ high) and sediment structured at the bottom of water channel suggest important water flow through the cave, which can exceed $1 \mathrm{~m}^{3} / \mathrm{s}$. Water is entering the cave through the roof (supersaturated water; autogenic recharge) and from the cave system Hang Vom (allogenic recharge). The latter was proved with allogenic sediments and parts of a wood, which is entering the Thien Duong through narrow phreatic channel downstream of Cot Nhu Da. Identical tributary was noticed further upstream, $2.5 \mathrm{~km}$ from the entrance to Thien Duong. This water is entering Thien Duong just at the highest discharges, when Hang Vom is not able to transfer all the water that is entering the underground cave system. At that time, piezometric level rises above the bottom of Thien Duong and floods the lower parts of a cave. Regarding to morphological observation, this water is together with autogenic recharged water nearly equilibrated with respect to $\mathrm{Ca}^{2+}$ and does not corrode rimstone dams. Cave rock relief is therefore not recent or develops at slower rate than rimstone dams. Because of its high turbidity, silt, loam and clay are deposited at places with slower water flow.

The second important inflow is entering the cave through the roof and has much more stable discharge in comparison with allogenic recharge. It depends on intensity and durability of precipitation. Regarding to our morphological observation it is clear, that percolation water is supersaturated with respect to $\mathrm{Ca}^{2+}$ and therefore deposits calcite. The majority of flowstone deposition takes place at stalagmites; the smaller part is deposited at stalactites and at rimstone dams. If they are located in the main water channel, they are usually covered with thin layer of clay.

Periodical floods in Thien Duong are a serious threat to touristic infrastructure, if the cave is developed as a show cave. Since the time of their appearance, frequency, durability and their height are of the highest value to estimate their potential threat to touristic development, monitoring of water level is necessary. Therefore we installed data-logger for water level and temperature measurements, which shall give us information on water oscillation within one hydrological year (2009-2010) but it was washed away due to too weak fixation by severe flood in October 2010 and not found till now.

\section{EVALUATION OF HEAVEN'S CAVE'S POTENTIAL FOR TOURISM}

The cave is practically invulnerable in the meteorological sense, since at least in winter and summer it is extremely well ventilated. The absence of archaeological finds and palaeontological remains keeps it invulnerable in this sense too. The cave is most vulnerable in the sense of the morphology of deposited sediments (speleothems and loam). The most sensitive features are rimstone dams. Walking alternately over loam and calcite surfaces results in the loam being transferred to the speleothem-covered surfaces. It is not possible to define speleobiological risks and guidelines on the basis of present research and knowledge. Further research indicating the numbers of animal species, their rarity and their protection, would be necessary. Due to high biodiversity of Phong Nha-Ke Bang national park and long geomorphic evolution, high biodiversity can be expected also in the cave. The most serious threat for touristic infrastructure in Heaven's Cave are periodical floods.
Large stalagmites and pillars, and rimstone dams (Fig. 5) are the greatest tourist attraction of the cave, since they are of above-average dimensions and are perfectly conserved. Owing to their fragility they are also most at risk in the case of unsuitable walking through the cave. For tourists from non-tropical areas, the location of cave formations so close to the entrance is surprising, but scientifically expected in a tropical climate due to the absence of frost weathering.

Another unique attraction is Heaven's Cave's position as part of the long cave system of Hang Vom, one of the longest and largest water caves in the world. Hang Vom itself is dangerous for visitors because of the frequent and sudden floods, but the rise in the water level in Heaven's Cave is presumably considerably slower, more predictable, the exit from the cave is higher than the highest possible flood and quite near the furthermost point of the measured section of the cave. 


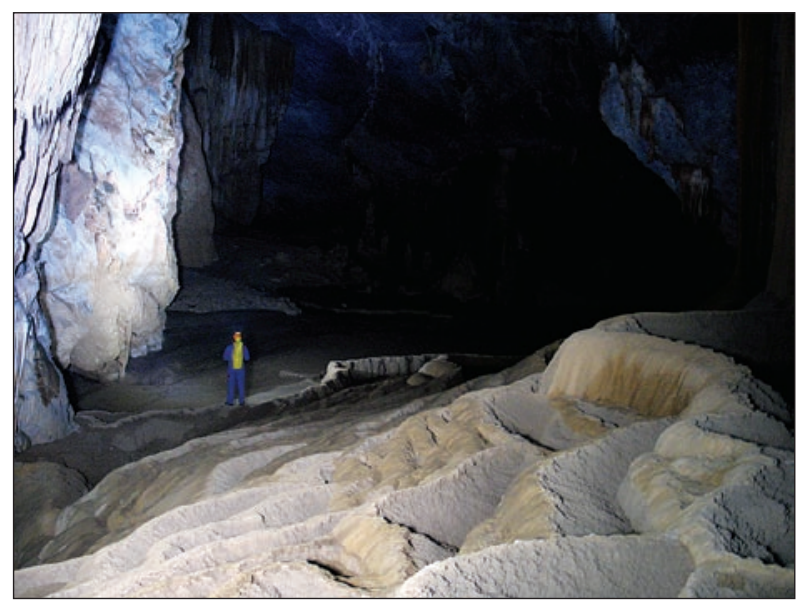

Fig. 5: Rimstone dams-the biggest attraction of the Heaven's Cave (Photo: M. Prelovšek).
Heaven's Cave has very good educational potential since it offers a good and varied insight into speleologi$\mathrm{cal}$ and karst phenomena, while the route to the cave and the beautiful environment of the Chay River offer a good insight into the biological characteristics of a humid tropical forest on karst rock.

Tourism in Phong Nha-Ke Bang National Park is mainly concentrated in the area of the Phong Nha and Tien Son Caves. Owing to their great attractiveness, these represent a considerable potential for tourism, which in our opinion, however, is far from being sufficiently exploited.

\section{POSSIBILITIES OF SHOW CAVE EQUIPMENT FOR THE CAVE AND ACCESS}

Adapting the Heaven's Cave for tourism purposes is a technically demanding project because of its specific geographical position (remoteness), somewhat unstable sediments and alluvial deposits, high ceiling and non-monitored fluctuation of water level. The cave is a sensitive ecosystem and all touristic influences should be evaluated. Due to cave's location in the national and UNESCO park, necessary permission from the relevant ministries of the Vietnamese government, and from UNESCO should be acquired.

Due to poorly defined development plan for Phong Nha-Ke Bang national park and unknown availability of financial resources, several proposals for paths and lighting in the cave have been drawn up (Fig. 6) at the request of the Vietnamese partners:

- path for adventure visits;

- path for mass tourism with all relevant infrastructure - classic cave visit;

- path with man-made tunnel to enable easier access to and exit from the cave.

An outline plan for classic cave visit has been drawn up for the laying-out of a 550-metre footpath for mass tourism. It has been proposed that the walking surfaces in the cave should be made of non-corrosive materials and be light and removable. The whole path should be built on pillars in order to avoid major building work and damage to the floor of the cave. Man-made tunnel below natural entrance would make the entrance easier for visitors. A proposal has been prepared of a 60-metre man-made tunnel that would enable visitors to avoid the steps that would otherwise be urgently necessary in the entrance section of the cave. This would probably increase the number of visitors, but here the opinion of UNESCO is decisive.

Three possibilities for lightning were proposed:

- traditional lighting (bulbs, spotlights),

- LED lighting,

- combination of traditional lighting and LED lighting.

To access the cave's entrance we proposed three variants of access. Access by footpath would follow the existing path through the rainforest, along the river and end with a steep ascent towards the cave entrance. In view of the great biodiversity and historical importance of the area, it could also serve as a nature/history trail if suitable explanations were provided. Access by road envisages the construction of a road $3 \mathrm{~km}$ long and $4-5 \mathrm{~m}$ wide from the car park to an esplanade outside the cave entrance. The road would be exclusively intended for the transporting of visitors to the cave by minibus or roadmobile. Visitors would leave their vehicles in the car park by the main road, where other tourist infrastructure would be built (information centre, restaurant, souvenir shops, toilets, etc.). Access to the cave could also be implemented by constructing a gondolatype cable car to carry visitors to the top of the overhanging cliff above the cave. From here visitors would be transported to the cave by vehicles. The idea was presented at the request of the Vietnamese partners, although the prevailing opinion is that such infrastructure does not suit UNESCO's guidelines for the natural environment in the park. 


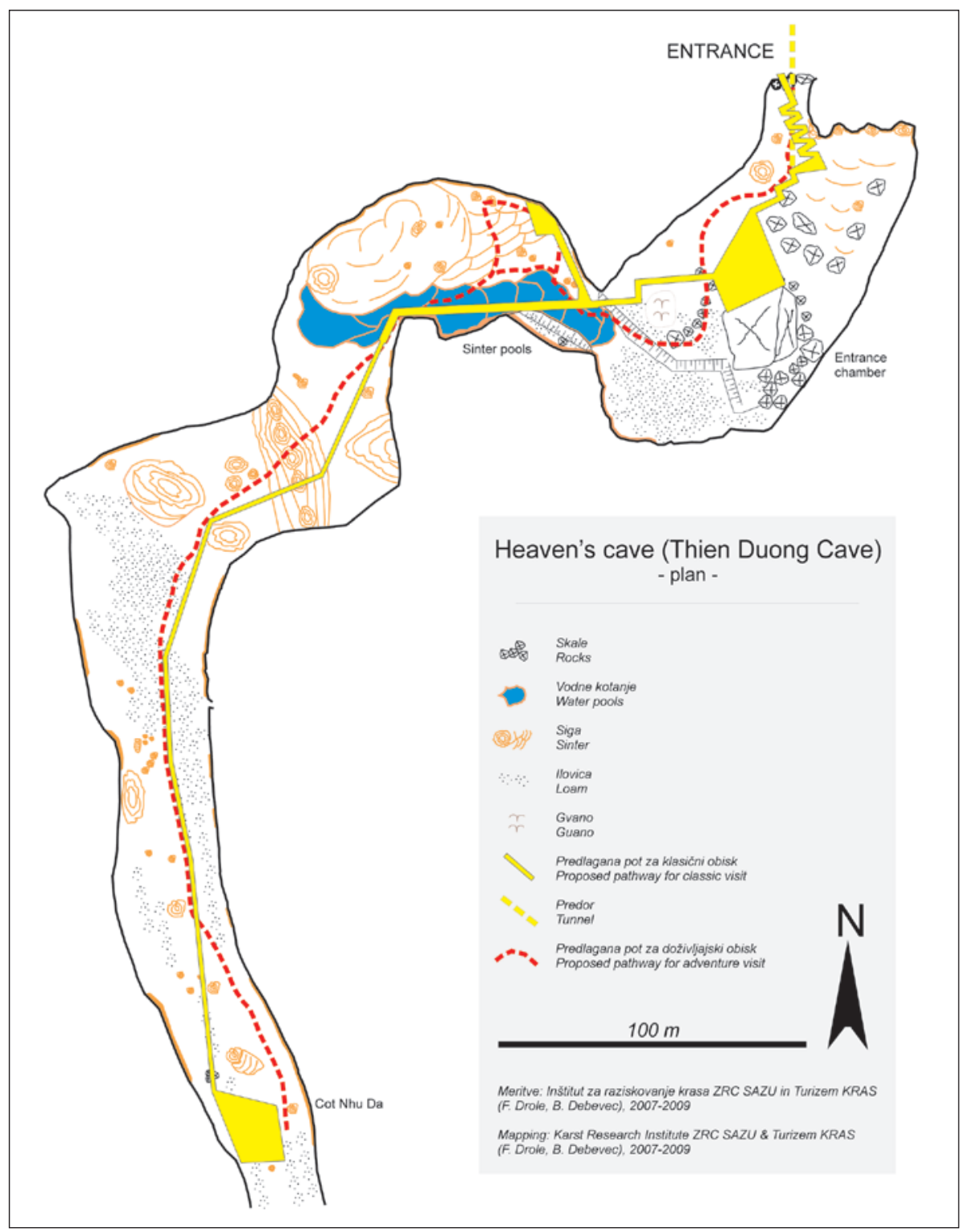

Fig. 6: Several proposals for cave visit.

\section{DEFINING THE TRAVELLERS NEEDS}

The aim of the project to develop a base for establishing tourism in the Phong Nha-Ke Bang National Park is to set up a comprehensive service, infrastructure and marketing mix which will help create an adequate range of primary tourist services to meet foreign tourists' needs, as well as a secondary range of tourist services, define relationships with stakeholders and establish a comprehensive system for promoting the national park for tourism purposes which could represent one of foundations for economic development in the future.

In view of the fact that tourism is still at a very basic level in Quang Binh province, where Phong Nha-Ke Bang National Park is situated, basic information about potential visitors, their structure, needs, preferences, etc. still had to be obtained.

\section{SURVEY}

Developers of the national park needed additional information on what kind of tourism services are sought after by foreign tourists, which at present time represent the only market segment with purchasing power. The aim was to define the motivational factors for choosing Vietnam as their travel destination as well as define the primary sources of information for doing so. Willingness to spend on different services was also a key question since it would enable developers to prepare a suitable strategy and development plans for establishing a modern tourist destination in Phong NhaKe Bang national park which would attract foreign investors in the first place.

The goal of the survey was to obtain primary data and answers on questions arising from ambition of preparing suitable strategy for development of national park. The data was collected via a questionnaire with personal interviewing of foreign tourists arriving at the Hanoi national airport. Questionnaire used for research was based on specification of key tourist resources and attractions of a tourist destination adopted from works of Richie and Crouch (2005) and modified to fit the demands of our research. Data collection was taking part in the first months of 2009. There were a total of 978 responses collected.

\section{SAMPLE DEMOGRAPHICS}

In the sample, nearly two thirds $(63.5 \%)$ of respondents were male. The respondents were very well educated, almost half (47\%) of the respondents had university degree and an additional $40 \%$ had some technical or professional college. The educational structure of visitors to Vietnam is 
above typical when compared to educational structure of American population (U.S. Census Bureau 2009), since the majority of visitors are well educated. The reason for this should be sought in the fact that Vietnam is not a resort and entertainment destination, and rather for the majority it is a quite exotic and unspoiled destination, attractive for those potential visitors who are seeking a higher level of experience - the experience of local culture, unspoiled nature, exploration and so on. The survey showed the relatively high average income of visitors to Vietnam, with average monthly income exceeding USD 3,000. This finding aligns with the high educational structure of visitors (more highly educated people tend to hold more responsible and better paid jobs), and confirms the impression that given the type of destination, Vietnam is visited by wealthier people. In view of the sparse representation of people from lower income brackets, we might even surmise that Vietnam is not a destination for those in lower income brackets, something probably related to the relatively high costs of travel to Vietnam (costs of air travel, tourist visas, etc.). Those visitors from lower income brackets who nevertheless travel to Vietnam probably include, therefore, either family members, who are not the primary payers of the travel costs, or students, who through this kind of travel satisfy their need for new discoveries in exotic destinations, and their relatively low cost of everyday living in their home locations enables them to save up the necessary funds despite their relatively low personal income.

\section{TRAVEL HABITS}

Only a minority of respondents, $15 \%$, traveled to Vietnam alone, most people (37\%) traveled to Vietnam with family. Only one fifth of the respondents came with an organized tourist group, somewhat above one quarter (27\%) came with friends or business partners. The majority of those making their own travel arrangements travel with their families. A fair percentage of "family" travelers also travel with organized groups, as do almost all those traveling in a group. Those traveling alone make their own arrangements. The vast majority of those who had their trip organized by the employer are traveling with colleagues or business partners. The majority of respondents (about 30\%) travel in any time of the year, for the rest the frequencies for traveling in spring or autumn are somewhat higher than the frequencies for summer and winter. The length of stay of the respondents is fairly equally distributed among less than seven days, seven to 10 and more than 10 days.

Most visitors have at least a rough plan about what they want to visit and see in Vietnam, a very small minority decides on-the-go. Travel agents are the most important source of information, particularly to those that have a detailed plan, whereas those who only have a rough plan mostly use internet as a source. Internet is by far the most important source of information for those that decide on their route on-the-go.

\section{STAY AND TRAVEL}

The findings indicate that the most desirable accommodation is in the $3^{*}$ and $4^{\star}$ categories. Five-star facilities are demanded chiefly by business travelers. Renting a car is relatively popular among those that stay in three and four star hotels, whereas those that stay in five star hotels travel almost exclusively by plane.

\section{FACTORS INFLUENCING THE DECISION TO VISIT VIETNAM}

\section{TOURIST ATTRACTIONS}

We grouped the reasons concerning the attractions into five groups: natural features, history and culture, special events, tourist attractions and entertainment, methodology adopted from works of Richie and Crouch (2005). Each of the separate groups of reasons was measured with a scale, for each scale we had four to five items. We verified the validity of scales with the help of exploratory factor analysis (we used principal axes factoring and varimax rotation). Validity of scales was confirmed, as all items load on scales as expected. The reliability of scales was tested with Crombach's alpha, all scales are reliable with alphas above 0.7 .

The most important reason to visit Vietnam, as measured by the scale score, is to see the natural attrac- tions of the country. These are followed by history and culture and the tourist attractions - the difference between these two categories is not statistically significant. If three is the mid-point separating the important from les important reasons, entertainment is statistically just slightly above that border. Special events score the lowest of all the reasons and we could say that on average they do not represent an important reason to visit Vietnam. It is interesting however that the official promotional material handed out by Vietnamese embassies focuses precisely on promoting festivals and events, but visitors to Vietnam do not regard these as an important reason to travel to Vietnam. 


\section{SERVICE}

Respondents were also asked to rate the importance of different services on their decision to visit Vietnam. The most important reason was a good command of world languages, spoken by the local guides, followed by well organized excursions and availability of medical treatment. The difference between these two categories is not statically significant. In the eyes of the travelers Vietnam is still considered to be a country with high potential risk when medical treatment is needed. Therefore a lot of consideration is given to availability of European standard medical treatments and ability to communicate with residents. Food and accommodation is the least important of the proposed reasons. However, other services are significantly above the threshold of three, which means that they are important as well.

\section{BUDGETARY CONSIDERATIONS}

Respondents are on average prepared to pay 61.7 dollars per room per night when staying in Vietnam. Almost one in six visitors is prepared to pay more than 80 dollars, about $6 \%$ of respondents would pay less than 80 dollars. Majority of people would pay from 40 to 60 dollars. On average the respondents would spend 50.3 dollars per person per night on food and shopping. Additionaly, respondents are prepared to spend an average of nearly 30 dollars per person per activity like sports, guided visit, riverboat trips, etc. Most respondents would spend between 20 and 30 dollars, $15 \%$ of respondents would spend more than 40 dollars. As expected the budgets increase with the prefered star rating of hotels. It is especially interesting that the preference of tourists for a lower category of accommodation does not necessarily mean any less willingness to spend on other things ( $\mathrm{F} \& \mathrm{~B}$, shopping etc.) and to take part in various spending-related activities (experiencing nature, visits to natural and cultural sites, etc.). Indeed the survey has shown that while the willingness to spend on overnight accommodation falls, the willingness to spend on other goods falls much more slowly.

\section{CONCLUSION}

Heaven's Cave, as part of one of the longest water cave systems in the world (Hang Vom), is a speleologically important part of Phong Nha-Ke Bang National Park. From this point of view Heaven's Cave is very suitable for the development of a more educational form of tourism in the sense of karstology and speleology in the wider area, while it also has a number of remarkable cave formations (rimstone dams, massive stalagmites and dripstone pillars). Although flood water occasionally appear in the cave, these are believed to be considerably less intensive and of shorter duration than those in Hang Vom but they can be more frequent and powerful due to climate change over the next 50 years. The present-day development of cave for tourism should take into consideration such climate changes. The biggest weakness of the cave is access, which in the case of major investment in the cave would require significant development in the park. From this point of view it would be essential to obtain the consent of UNESCO.

The development of the cave as a show cave must proceed gradually, step by step. Any rapid development with major investments could have negative consequences in the natural, social and economic environment, with lasting negative impacts, above all on the environment. For this reason the gradual development of alternative or adventure tourism has been proposed. This could be expanded, depending on the needs of visi- tors, to a more intensive exploitation of natural sights (setting up a path through the cave for classic tourist visits, building a road, etc.).

Developing the cave as a show cave would necessarily have to include the other tourist attractions offered by this area. One opportunity is the Ho Chi Minh Trail, which consists of a maze of cart tracks, footpaths and river routes. During the Vietnamese War (1959-1975) it played a key role in the supply of materiel to the Republic of Vietnam in the south from the Democratic Republic of Vietnam in the north. The trail ran through the mountainous area of Laos, Cambodia and part of Vietnam, and played a key role in the victory of "North" Vietnam over "South" Vietnam. The starting point of the route towards the south was in fact in the area of Phong Nha-Ke Bang Park. Another interesting feature is the path that leads us through the tropical rainforest in the direct vicinity of the River Chay. The Phong Nha-Ke Bang Park has exceptionally well conserved primary vegetation, which is a rarity in South-East Asia. Despite the fact that this criterion was considered slightly too weak for the park to be included on UNESCO's natural heritage list, we may still consider it to be exceptional. On the contrary, it appears that the potential for tourism is not being sufficiently exploited. It would make sense to include it in the route to Heaven's Cave. The view that opens up of the varied relief around the cave could be incorporated into 
education about the characteristics and development of tropical cone karst.

The chief reason for visiting Vietnam given is the natural beauties of the country, which is a highly favourable point for development of the national park. In general visitors to Vietnam are seeking primarily natural features (e.g. Heaven's Cave), historical and cultural facilities (it might be possible to set up a theme village presenting local customs, local architecture etc.) and museums (such as the Ho Chi Minh Trail Museum).The high average personal income of visitors represents a good starting point for developing tourism, since it makes possible an extensive range of services and justifies the high expectations of tourist spending.

The Survey results show moderate willingness to spend on overnight stay. With regards to motivational factors influencing decision to visit Vietnam we can conclude that more adventures type of tourism is currently present in Vietnam. For primary development of tourism infrastructure therefore the ideal choice for category of accommodation in the national park would correspond to European standard of 3 stars - being affordable, reliable and safe without unnecessary luxury. A preference to lower category of accommodation does not necessarily mean any less willingness to spend on other things ( $F \& B$, shopping etc.) and to take part in various spending-related activities (experiencing nature, visits to natural and cultural sites, etc.).

Services to which special attention should be paid in planning the tourist development of the national park include:

- a mastery of world languages (English, French, German, etc.);

- organised tours and excursions on which tourists can discover the beauty of Vietnam;

- accessibility of medical care. While travelling to undeveloped or/and tropical countries one of the most important factors is a sense of safety; ensuring highquality medical care contributes significantly to a sense of safety;

- food and accommodation capacities in line with European or US standards.

It was also found that the majority of people carefully plan their trip to Vietnam in advance, meaning that they formulate their planned itinerary through Vietnam and the list of tourist attractions that they want to see in advance. For the national park it is therefore extremely important that following the establishment of tourist infrastructure, the park begins marketing activities in the main emitting markets and thereby ensures that information is available right at the travel-planning stage, which tourists are doing in their home environment. One of the most important information sources appears to be the internet, where the majority of tourists who travel to Vietnam gather information about their trip. It is therefore vital for the successful operation of the national park that it is presented properly on the web.

While primary objective of the developers was to obtain information on what kind of tourism attractions to offer, what kind of infrastructure to build and how to successfully promote national park on foreign markets, they should also consider implementation of proper destination management model in order to successfully manage relations among key stakeholders in the region, especially between public sector, local residents, developers and investors. A good starting point would be to investigate the existing relationships between stakeholders with methodology proposed by Semeja (2011) and, based on findings, implement a modern relation-based tourist destination model.

Survey findings are showing that there is good potential for tourism development in the area of Phong Nha-Ke Bang National Park. Following the guidelines set by this paper, the developers should focus on travellers needs and develop comprehensive and sustainable tourism destination which will support prosperity for local people and become one of the sought-after tourist attractions of Vietnam.

Once again this study pointed out that not only physical aspect with monitoring should be taken into consideration for development of caves for tourism (Cigna 2004, Mulec \& Gabrovšek 2008) but human, territorial, and economic aspects as well. Nevertheless, this is only general guideline for study and different emphasis should be made depending on the needs at each location.

\section{ACKNOWLEDGEMENTS}

The Slovene team is grateful to colleagues from the Vietnamese company CivideC for substantial support in Vietnam during study of the Heaven's Cave and its suit- ability to be adapted for tourist purposes. We are also grateful to Slovene Ministry of Higher Education, Science and Technology that partly financed our research 
in the framework of the programme Science promotion. The authors would like to thank both reviewers (Elery
Hamilton Smith and Mélanie Duval) for their valuable comments.

\section{REFERENCES}

Cigna, A. \& E. Burri E, 2000: Development, management and economy of show caves.- International Journal of Speleology, 29, 1-4, 1-27.

Cigna, A., 2004: Vulnerability of the Cave Environment.In: Zupan Hajna, N. (ed.). $4^{\text {th }}$ International ISCA Congress: Use of Modern Technologies in the Development of Caves for Tourism, $21^{\text {th }}-27^{\text {th }}$ October 2002, Postojna, Slovenia. Postojnska jama turizem, 185-191, Postojna.

Hamilton-Smith, E., 2009: The World's Biggest Cave!.ACKMA Journal, 75, p. 31.

Limbert, H., 2010a: Hang Vom System Overview.- [Online] Available from: http://www.vietnamcaves.com [Accessed January 14, 2010].

Limbert, H., 2010b: Longest Caves of Vietnam.- [Online] Available from: http://www.vietnamcaves.com [Accessed January 14, 2010].

Limbert, H., 2010c: Summary of Caving Expeditions to Quang Binh Province.- [Online] Available from: http://www.vietnamcaves.com [Accessed January 14, 2010].
Mulec, J. \& F. Gabrovšek, 2008: Ureditev turistične jame.In: Luthar, O., Dobrovoljc, H., Fridl, J., Mulec, J. \& M. Pavšek (eds.) Kras. Trajnostni razvoj pokrajine.ZRC Publishing, pp. 295-299, Ljubljana.

Ritchie Brent, J.R. \& I. Crouch Geoffrey, (2005): The Competitive Destination. A Sustainable Tourism Perspective.- Cabi Publishing, pp. 267, Cambridge.

Semeja, A., 2011: Developing a tourist destination model and analysis of key establishment factors in case of tourist destination Kras.- PhD Thesis. University of Ljubljana, Faculty of Economics, pp. 172.

Slabe, T., 1995: Cave rocky relief and its speleogenetical significance.- Znanstvenoraziskovalni center SAZU, pp. 128, Ljubljana.

U.S. Census Bureau, 2010: Educational Attainment in the United States.- [Online] Available from: http:// www.census.gov/hhes/socdemo/education/data/ cps/2009/tables.html [Accessed January 14, 2010].

World Heritage List Nomination Form: The Phong NhaKe Bang National Park, Vietnam. 2000. 